\title{
Comparative analysis between prediction models in codes and test data for shear strength
}

\section{Análise comparativa entre modelos de predição de norma e dados de ensaios na determinação da resistência ao cisalhamento}

F. P. HIRATA a

pessotohirata@yahoo.com.br

R. G. M. DE ANDRADE rodolfogma@gmail.com

J. C. DELLA BELLA a dbella@usp.br

\begin{abstract}
Since the beginning of twentieth century, along with academic publications of Ritter and Mörsch, several studies have been done in order to understand shear strength in reinforced concrete elements. Approximately 1,200 laboratory tests results of reinforced concrete beams under shear stresses were used in a comparative analysis among values from prediction models of codes and laboratory tests results, enabling classification of the codes according to their applicability in several tests intervals. Although the Brazilian Code NBR 6118 (2007) showed good results in usual ranges of parameters, it presented unsatisfactory results on the following cases: low and medium shear transverse reinforcement rate.
\end{abstract}

Keywords: shear design, shear strength, standards comparison, standards applicability.

\section{Resumo}

Desde o início do século XX, com as publicações de Ritter e Mörsch, diversos modelos de cálculo foram desenvolvidos para tentar avaliar o valor da força cortante resistente em elementos em concreto armado. Com um banco de dados de cerca de 1.200 resultados de ensaios de laboratório de vigas de concreto armado, solicitadas por esforços de cisalhamento, efetuou-se a análise comparativa entre os valores de predição das principais normas e os resultados de ensaios, permitindo qualificar o modelo de predição das normas quanto sua aplicabilidade em diversos intervalos de ensaios. O modelo de predição da norma brasileira NBR 6118 (2007) [1] apresentou resultados satisfatórios nos intervalos usuais dos parâmetros, porém pouco satisfatórios para elementos com média e baixa taxa de estribos.

Palavras-chave: dimensionamento ao cisalhamento; resistência ao cisalhamento; comparação entre normas; aplicabilidade das normas. 


\section{Introduction}

In several studies a discrepancy in noticed when laboratory results are compared to analytical values of reinforced concrete's shear strength. There are several phenomena that contribute to the behavior of reinforced concrete under tangential and axial loads which contribute to the previously mentioned discrepancy in estimating similar values to laboratory tests.

Leonhardt [2] presents a list of 21 factors that influence the shear strength of reinforced concrete elements, some with direct influence and others, indirect. Thus, creating a formulation considering the most significant factors becomes a complex activity, given the elevated number of factors that may influence the determination of shear strength.

Therefore, it is important to assess the formulations used within certain parameters ranges and especially in particular geometries.

\section{Methodology}

\subsection{Determination on Codes prediction values}

The results of Code's prediction models were obtained from electronic spreadsheets designed by the author, as well as the charts. The obtained data enabled the author to assess the influence of various Codes models when confronted to experimental tests. This study used four Codes: ACI 318 (2008) [3]; CSA A23.3 - 04 (2004 ) [4]; EUROCODE 2 (2004) [5] and NBR 6118 (2007). The prediction models of $\mathrm{ACI}$, EUROCODE and NBR have different formulations to evaluate the resistance values for reinforced concrete elements due to strut under ultimate compression strength, described as shear-compression failure by Fusco [6]. The same models have different formulations for elements with and without stirrups under ultimate tensile strength, described as shear-tensile failure by Fusco [ 6 ]. CSA Code presents a single formulation for both shear-compression and shear-tensile failures.

Table 1 summarizes the formulations of the studied models, whereas the shear stress, $\tau$, is represented by the ratio of shear force, $V$, and the section's effective area $b_{w} \cdot d$.

In order to obtain the maximum shear strength according to EUROCODE and NBR's Model II, there were created some optimization scripts that vary the strut's angle. Limitation to maximum angle reduction was according to each Code, to strut's ultimate compression strength, and to bending reinforcement.

\subsection{Database description}

The database comprises a compilation of 1,235 laboratory tests results on reinforced concrete beams, being 547 reinforced concrete beans with stirrups and 688, without. This paper focus on reinforced concrete beams with stirrups. All tested beams presented longitudinal bars (for bending moment) and were perpendicularly loaded to them longitudinal axis. The loading can be a single concentrated load in mid span, equally spaced concentrated loads, or a knife-edge load along the entire beam.

The failure modes were separated in groups so each ultimate limit state could be represented.

The test data summary used in this paper is shown in Table 2, which contains results for elements with shear reinforcement. These results are related to shear force failure.

\section{Table 1 - Prediction Models Equations in order to obtain ultimate shear strength}

\begin{tabular}{|c|c|c|c|c|}
\hline \multirow{3}{*}{ Codes } & \multicolumn{4}{|c|}{ ULS Equations } \\
\hline & \multirow{2}{*}{$\begin{array}{l}\text { ULS shear-compression } \\
\qquad \tau_{\mathrm{rd}, \mathrm{c}}(\mathrm{MPa})\end{array}$} & \multicolumn{2}{|c|}{$\begin{array}{c}\text { ULS shear - tensile } \\
\tau_{\text {rd, }}=\tau_{c}+\tau_{\text {sw }}(\mathrm{MPa})\end{array}$} & \multirow[t]{2}{*}{ Comments } \\
\hline & & $\tau_{\mathrm{c}}(\mathrm{MPa})$ & $\tau_{\mathrm{sw}}(\mathrm{MPa})$ & \\
\hline NBR 6118 Model I & $0,27 .(1-f c / 250) . f c$ & $\tau_{c}=\tau_{c 0}=0,126 . \mathrm{fc}^{2 / 3}$ & $0,9 \cdot \rho_{w} \cdot f_{y}$ & $\mathrm{q}=45^{\circ}, \mathrm{fc} \leq 50 \mathrm{MPa}$ \\
\hline NBR 6118 Model II & 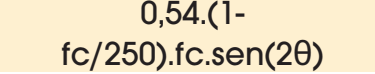 & $\begin{array}{c}\tau_{\mathrm{co}:}(\tau \mathrm{rd}, \mathrm{C}-\tau \mathrm{sd}) /(\tau \mathrm{rd}, \mathrm{c}- \\
\tau \mathrm{c} 0)<\mathrm{t}_{\mathrm{c} 0}\end{array}$ & $0,9 \cdot \rho_{w} \cdot f_{v} \cdot \operatorname{cotg} \theta$ & $30^{\circ} \leq \mathrm{q}<45^{\circ}$, fc $\leq 50 \mathrm{MPa}$ \\
\hline EUROCODE 2 & $0,45 . n 1 . f c \cdot s e n(2 \theta)$ & 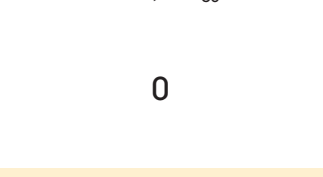 & $0,9 \cdot \rho_{w} \cdot f_{y} \cdot \operatorname{cotg} \theta$ & $\begin{array}{c}\mathrm{nl}=0,6, \text { for } \mathrm{fc} \leq 60 \mathrm{MPa} \\
\mathrm{nl}=0,9-\mathrm{fc} / 200>0,5, \text { for } \mathrm{fc} \\
>60 \mathrm{MPa} \\
1 \leq \cot \mathrm{q} \leq 2,5\end{array}$ \\
\hline CSA & $0,25 . \mathrm{fc}$ & $\beta . \mathrm{fc}^{1 / 2}$ & $0,9 \cdot \rho_{w} \cdot f_{v} \cdot \operatorname{cotg} \theta$ & $\begin{array}{l}\beta \text { e } \theta \text { are obtained by } \\
\text { simple equations as a } \\
\text { function of axial strain } \\
\text { fc } \leq 64 \mathrm{MPa}\end{array}$ \\
\hline $\mathrm{ACl} 318$ & $0,83 . f c l / 2$ & $0,17 . f c^{1 / 2}$ & $\rho_{w} \cdot f_{y}$ & - \\
\hline
\end{tabular}




\subsection{Analysis criteria}

After selecting some database results, it was possible to assess and compare those results to the Codes' prediction models.

This paper names as "accepted" all the parameters used within an established range by a given Code. On the other hand, "denied" defines a parameter which is found outside the range under analysis. Thus, using parameters outside the valid range would be, for example, to calculate a predictive value using a code resistance value of concrete above the maximum allowed.
This paper considered that the section strength obtained throughout the test is the ultimate strength.

Illustrated in Table 3, the ratio between the laboratory's ultimate value, $V_{\text {exp }}$, and ultimate analytical value, $V_{u}$ is shown as $V_{\text {exp }} V_{u}$. In general terms, $V_{u}$ comprises the influence of concrete's shear strength $\left(V_{c}\right)$ and stirrup's strength $\left(V_{s}\right)$. Thus, $V_{u}=V_{c}+V_{s}$.

This paper names the shear strength as $V_{d}$, concrete's partial safety coefficient as $\Phi_{\mathrm{c}}$, and $\Phi_{\mathrm{s}}$ for stirrups' partial safety coefficient. The ultimate safety coefficient will be stated as $\Phi$. For elements with stirrups, ultimate safety factor, $\Phi$ depends on the weighing between $V_{c}$ and $V_{s}$. For example, elements with high stirrups rate, $\Phi$

\section{Table 2 - Database for RC beams with stirrups (part 1)}

\begin{tabular}{|c|c|c|c|c|c|c|c|}
\hline Author & $\begin{array}{l}\text { Number } \\
\text { of tests }\end{array}$ & $\mathrm{d}(\mathrm{cm})$ & $\mathrm{f}_{\mathrm{c}}(\mathrm{MPa})$ & $\rho_{1} \%$ & $\rho_{\mathrm{sw}} \%$ & $\mathbf{a} / \mathbf{d}$ & $\begin{array}{c}\rho_{\text {sw.fyk }} \\
(\mathrm{MPa})\end{array}$ \\
\hline $\begin{array}{l}\text { Anderson, N. S. } \\
\text { Ramirez, J. A.(7) }\end{array}$ & 13 & $34,5-42,53$ & $28,69-42,76$ & $2,31-2,65$ & $0,39-0,53$ & $2,15-2,65$ & $2,14-2,83$ \\
\hline $\begin{array}{c}\text { Angelakos, D.; Bentz, E. C.; } \\
\text { Collins M. P. (8) }\end{array}$ & 6 & 92,50 & $21-80$ & $0,5-1,01$ & 0,08 & 2,92 & 0,40 \\
\hline $\operatorname{Bahl}(1968)^{a}$ & 4 & $30-120$ & $25,1-26,8$ & 1,26 & 0,15 & 3,00 & 0,66 \\
\hline Bresler ; Scordelis (9) & 10 & $39-46,61$ & $23,17-38,75$ & $1,8-3,66$ & $0,1-0,38$ & $2,35-6,98$ & $0,33-1,26$ \\
\hline Bresler; Scordelis (1966) ${ }^{a}$ & 22 & $45,67-46,25$ & $23,17-26,75$ & $1,67-2,34$ & $0,1-0,21$ & $3,95-4,01$ & $0,35-0,7$ \\
\hline Cho, S. H. (10) & 24 & 21,50 & $52-73$ & 3,77 & $0,2-1,8$ & $1,5-2,5$ & $0,78-6,98$ \\
\hline $\begin{array}{l}\text { Cladera, A.; } \\
\text { Marí, A. R. (11) }\end{array}$ & 11 & $35,1-35,3$ & $49,9-87$ & $2,28-2,99$ & $0,11-0,24$ & $3,06-3,08$ & $0,58-1,29$ \\
\hline Clark, A. P. $(1951)^{b}$ & 51 & $31,37-39,4$ & $13,79-87$ & $1,63-3,42$ & $0,24-1,22$ & $1,16-3,08$ & $1,13-4,04$ \\
\hline Collins e Kuchma (12) & 4 & $45,9-92$ & $71-75$ & $1,03-1,36$ & $0,13-0,16$ & $2,5-2,72$ & $0,65-0,8$ \\
\hline $\begin{array}{c}\text { Debaiky, S. Y.; } \\
\text { Elniema, E. I. (13) }\end{array}$ & $\begin{array}{l}9 \\
2\end{array}$ & 26,00 & $17,23-31,4$ & $1,93-3,02$ & $0,2-0,42$ & $1,92-3,46$ & $0,63-1,33$ \\
\hline $\begin{array}{l}\text { Elstner, Moody, Viest, } \\
\text { Hognestad (1955) }\end{array}$ & & 30,50 & $23-24$ & 4,76 & $0,95-1,47$ & 2,00 & $2,98-4,81$ \\
\hline $\begin{array}{c}\text { Elzanaty, Nilson } \\
\text { e Slate (14) }\end{array}$ & 3 & 26,60 & $20,7-62,8$ & $2,5-3,3$ & 0,17 & 4,00 & 0,65 \\
\hline Fernandes, G. B. (15) & 5 & 28,00 & $61,1-78,5$ & $4,1-6,18$ & $0,25-0,38$ & $3,57-5,36$ & $2,14-3,21$ \\
\hline Fukuhara, Kokusho (16) & 19 & $34-36$ & $20-32$ & $0,61-3,21$ & $0,12-1,13$ & $1,76-2,35$ & $0,63-5,01$ \\
\hline 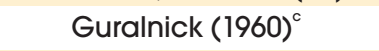 & 9 & $30,6-31$ & $17-38$ & $1,41-4,38$ & 0,24 & $2,95-2,99$ & 1,26 \\
\hline $\begin{array}{l}\text { Haddadin, Hong, } \\
\text { Mattock (17) }\end{array}$ & 22 & 38,10 & $13-44,9$ & $3,79-7,58$ & $0,19-1,26$ & $2,5-6$ & $0,68-4,77$ \\
\hline $\begin{array}{c}\text { Hsiung, W.; } \\
\text { Frantz, G. C.(18) }\end{array}$ & 4 & 41,91 & 43,00 & 1,82 & $0,21-0,22$ & 3,00 & 0,62 \\
\hline $\begin{array}{l}\text { Karayiannis e } \\
\text { Chalioris (1999) }\end{array}$ & 8 & 26,00 & 26,00 & $1,47-1,96$ & $0,04-0,25$ & $2,77-3,46$ & $0,11-0,64$ \\
\hline $\begin{array}{l}\text { Kokusho, Kobayashe, } \\
\text { Mitsugi, Kumagai (1987) }\end{array}$ & 9 & 34,00 & $20-38$ & 3,16 & $0,15-1$ & 1,76 & $2,09-14,31$ \\
\hline $\begin{array}{l}\text { Kong, P. Y. L.; Rangan, } \\
\text { B. V. }(1998)^{d}\end{array}$ & 43 & $19,8-54,2$ & $63,6-89,4$ & $1,66-4,47$ & $0,1-0,26$ & $1,75-3,3$ & $0,6-1,49$ \\
\hline $\begin{array}{c}\text { Krefeld, W. J.; } \\
\text { Thurston, C. W. (19) }\end{array}$ & 20 & 45,57 & $15,73-48,49$ & 2,22 & $0,06-0,16$ & 4,02 & $0,21-0,64$ \\
\hline $\begin{array}{l}\text { Lee, Kim; } \\
\text { Mansour (20) }\end{array}$ & 4 & $24,4-26,4$ & 42,00 & $2,67-3,6$ & $0,22-0,32$ & $2-4$ & $0,79-1,15$ \\
\hline
\end{tabular}




\section{Table 2 - Database for RC beams with stirrups (part 2)}

\begin{tabular}{|c|c|c|c|c|c|c|c|}
\hline Author & $\begin{array}{l}\text { Number } \\
\text { of tests }\end{array}$ & $d(\mathrm{~cm})$ & $\mathrm{f}_{\mathrm{c}}(\mathrm{MPa})$ & $\rho_{1} \%$ & $\rho_{\mathrm{sw}} \%$ & $a / d$ & $\begin{array}{l}\rho_{\text {sw.tyk }} \\
(\mathrm{MPa})\end{array}$ \\
\hline $\begin{array}{l}\text { Leonhardt; } \\
\text { Walther (1962) }\end{array}$ & 4 & 27,00 & $28,2-30,4$ & 2,47 & $0,41-0,59$ & 2,78 & $1,52-1,63$ \\
\hline $\begin{array}{l}\text { Leonhardt; } \\
\text { Walther (1961) }\end{array}$ & 1 & 82,50 & 23,84 & 9,44 & 2,83 & 3,03 & 11,71 \\
\hline $\begin{array}{l}\text { Leonhardt; Walther } \\
\qquad(1963)^{b}\end{array}$ & 1 & 27,00 & 28,16 & 2,02 & 2,02 & 0,58 & 9,39 \\
\hline Levi, F.; Marro, P. (1988) & 7 & 94,00 & $25-60$ & $3,5-5,3$ & $0,84-1,25$ & 4,20 & $4,03-6$ \\
\hline Lyngberg, B. S. (1976) ${ }^{e}$ & 2 & 54,00 & $25,7-26,6$ & 3,88 & 0,53 & 2,78 & $3,43-3,57$ \\
\hline $\begin{array}{l}\text { Matsuzaki, Nakano, } \\
\text { Watanabe (1990)' }\end{array}$ & 8 & 33,60 & $23-37$ & 2,88 & $0,19-1,18$ & 1,79 & $1,29-8,59$ \\
\hline $\begin{array}{l}\text { Mattock, A. H.; } \\
\text { Wang, Z. (21) }\end{array}$ & 8 & $31,5-34$ & $20-34,1$ & $2,07-3,16$ & $0,24-0,47$ & $1,76-3$ & $0,84-4,13$ \\
\hline $\begin{array}{l}\text { McGormley; Creary e } \\
\text { Ramirez (1996) }\end{array}$ & 12 & 41,90 & $35,3-56,7$ & 3,03 & 0,34 & 3,27 & 1,45 \\
\hline $\begin{array}{c}\text { Moody, K. G.; Viest, I. M.; } \\
\text { Elstner, R. C.; Hognestad, } \\
\text { E.(1954) }\end{array}$ & 2 & 53,34 & $22,42-25,38$ & 4,25 & $0,52-0,95$ & 1,52 & $1,7-2,88$ \\
\hline Moretto, O. (22) & 5 & $46,4-49,5$ & $23-33$ & 3,99 & 0,27 & $1,64-1,75$ & $0,85-1,02$ \\
\hline Mphonde; Frantz (23) & 12 & 29,80 & $22,1-83$ & 3,36 & $0,12-0,38$ & 3,60 & $0,35-1,03$ \\
\hline $\begin{array}{l}\text { Nishiura, Makitani, } \\
\text { Shindou (1993) }\end{array}$ & 6 & 33,60 & $20-33$ & 2,88 & $0,4-0,89$ & 2,38 & $3,32-7,39$ \\
\hline $\begin{array}{c}\text { Ozcebe, G; Ersoy, U; } \\
\text { Tankut, T. (24) }\end{array}$ & 13 & $31-32,5$ & $58-82$ & $1,93-4,43$ & $0,14-0,28$ & $3-5$ & $0,35-0,71$ \\
\hline Peng (25) & 8 & 27,40 & $29,3-33,7$ & 2,70 & $0,05-0,37$ & 3,10 & $0,3-1,68$ \\
\hline Piyamahant Songkramc & 4 & 35,90 & $41,5-46,15$ & 1,06 & $0,04-0,08$ & 3,00 & $0,12-0,28$ \\
\hline $\begin{array}{l}\text { Placas, A.; Regan, } \\
\text { P. E. (26) }\end{array}$ & 44 & $25,4-26,4$ & $12-57$ & $0,98-4,16$ & $0,14-0,84$ & $3,36-7,2$ & $0,38-2,25$ \\
\hline $\begin{array}{l}\text { Rajagopalan, K. S.; } \\
\text { Ferguson, P. M. (27) }\end{array}$ & 3 & $26,42-26,59$ & $27,04-33,93$ & $1,71-1,74$ & $0,21-0,23$ & $4,16-4,23$ & $0,71-0,72$ \\
\hline Rangan, B. V. (28) & 4 & 56,30 & $30,2-36,5$ & $8,35-9,81$ & $1,53-3,19$ & 2,49 & $7,42-15,47$ \\
\hline $\begin{array}{l}\text { Rodriguez, Bianchini, } \\
\text { Viest, Kesler (1959) (29) }\end{array}$ & 12 & $30,9-32,6$ & $19-25$ & $2,6-2,74$ & $0,37-1,11$ & $1,99-2,29$ & $1,28-3,51$ \\
\hline $\begin{array}{l}\text { Roller, J. J.; Russell, H. G. } \\
\text { (1990) (30) }\end{array}$ & 10 & $55,88-76,2$ & $72,42-125,32$ & $1,73-7,29$ & $0,08-1,76$ & $2,5-3$ & $0,34-8,05$ \\
\hline $\begin{array}{c}\text { Sarsam, K. F.; Al-Musawi, } \\
\text { J. M. S. (31) }\end{array}$ & 14 & $23,2-23,5$ & $39-80,1$ & $2,23-3,51$ & $0,09-0,19$ & $2,5-4$ & $0,76-1,53$ \\
\hline
\end{tabular}

approaches the value $\Phi_{s}$. In the most general case, $\Phi$ is obtained as shown in Table 3.

NBR 6118 (2007) states that there are three main factors that reduces the element reliability when under shear loading: the variability of the strength of the materials, the difference between the trial tests and the effective structure, and deviations on construction site. Moreover, considerations on the kind of failure (brittle and ductile) and risks tolerance should be taken.

There a several considerations in order to guarantee the structures' reliability: construction execution detail, construction toler- ances, material strength, maximum and minimum number of reinforcement bars, etc. These considerations differ from the reliability considerations on the Codes prediction models, which presents similar results to those obtained in laboratory tests. This paper only analyses the codes predictions models.

As stated in Table 3, the safety coefficients comprise two values. The first one, $\Phi_{\text {mat }}$, is responsible for ensuring safety due to the variability and the possibility of a low material strength. The second, $\Phi_{\text {mod }}$, is responsible for the security by the inaccuracy of the model representation. 


\section{Table 2 - Database for RC beams with stirrups (part 3)}

\begin{tabular}{|c|c|c|c|c|c|c|c|}
\hline Author & $\begin{array}{l}\text { Number } \\
\text { of tests }\end{array}$ & $\mathrm{d}(\mathrm{cm})$ & $f_{c}(M P a)$ & $\rho_{1} \%$ & $\rho_{\mathrm{sw}} \%$ & $\mathbf{a} / \mathbf{d}$ & $\begin{array}{l}\rho_{\text {sw.fyk }} \\
(\mathrm{MPa})\end{array}$ \\
\hline Simplício (32) & 5 & $27-35,4$ & $69,3-73,5$ & $2,33-2,96$ & $0,1-0,22$ & $3,3-3,8$ & $0,75-1,54$ \\
\hline $\begin{array}{c}\text { Swamy e } \\
\text { Andriopoulos (1970) }\end{array}$ & 10 & $9,5-13,2$ & $25,9-29,4$ & $1,97-3,95$ & $0,06-0,6$ & $3-5$ & $0,17-1,33$ \\
\hline $\begin{array}{l}\text { Takagi, Okudeh, } \\
\text { Nitta (1989)f }\end{array}$ & 19 & 35,20 & $32-36$ & 3,09 & $0,19-1,21$ & 2,27 & $1,48-12,9$ \\
\hline $\begin{array}{c}\text { Tompos, E. J.; Frosch, } \\
\text { R. J. (33) }\end{array}$ & 4 & $42,55-85,09$ & $35,8-42,7$ & 1,00 & $0,08-0,15$ & 3,00 & $0,41-0,72$ \\
\hline Xie, Y. et. al. (34) & 9 & $19,81-20,32$ & $42,4-108,7$ & $3,2-4,54$ & $0,49-0,78$ & $1-4$ & $1,59-2,53$ \\
\hline $\begin{array}{l}\text { Yoon, Y. S.; Cook W. D.; } \\
\text { Mitchell D. (35) }\end{array}$ & 9 & 65,50 & $36-87$ & 2,80 & $0,08-0,24$ & 3,05 & $0,35-1,02$ \\
\hline $\begin{array}{l}\text { Zararis e Papadakis } \\
\text { (1999) (36) }\end{array}$ & 9 & 23,50 & $20,8-23,9$ & $0,68-1,37$ & $0,06-0,27$ & 3,60 & $0,16-0,73$ \\
\hline TOTAL & 547 & $9,5-120$ & 12 - 125,32 & $0,5-9,81$ & $0,04-3,19$ & $0,58-7,2$ & $0,11-15,47$ \\
\hline
\end{tabular}

After, similar safety criteria among the Codes were defined based on the previously presented values, $V_{\text {exp }}, V_{u}$ and $V_{d}$.

In order to assist the reliability analysis of the codes prediction models in determining the shear strength, a quality analysis based on the $V_{\text {exp }} N_{u}$ ratio within four ranges (as shown in Figure 1 and Table 4) was undertaken [43]. $V_{\text {seg }}$ is obtained from $V_{u}{ }^{*} \Phi_{\text {mod, }}$, being $\Phi_{\text {mod }}$ already described before. Indirectly related to monetary costs, $V_{\text {one }}$, defines another boundary. When a laboratory test gives a highly reliable value (i.e. above $1.1 V_{u}$ ), it is considered an onerous situation in terms of wasting material.

The criteria analysis is based on determining four ranges to compare $V_{\text {exp }}$.

The first range indicates that if $V_{\text {exp }}<V_{d}$, the code prediction model is considered dangerous and induces to unreliable values and is likely to fail. The second range indicates that if $V_{\text {exp }} \leq V_{d} \leq V_{\text {seg }}$, the model presents a low reliability. The third range, $V_{\text {seg }} \leq V_{\text {exp }} \leq V_{\text {one }}$ defines an optimum range, because the closer to unity the ratio $V_{\text {exp }} N_{d}$ is, the greater the strength of materials will be ( $\Phi_{\text {mat }}$ related). On the other hand, the greater the ratio $V_{\text {exp }} / V_{\text {seg }}$ is, the more reliable the model is ( $\Phi_{\text {mod }}$ related).

The fourth range defines if $V_{\text {exp }}>V_{\text {one }}$, there is a cost issue due to material waste. The security level is extremely higher than regular levels. This result induces to an elevated material consumption. The summary of the analysis intervals is expressed in Table 4.

The boundary values of the third range are to be defined. For beams with stirrups, it was necessary to determine $\Phi_{\text {mod }}$ 's average, which is considered as approximately equal to $\sqrt{\phi}_{\text {med }}$, being $\Phi_{\text {med }}$ the average of reducing strength coefficients of all Codes prediction models. From all the Codes [CSA (2004), Eurocode (2004), ACI (2008) and NBR 6118 (2007)], the partial safety coefficient

\section{Table 3 - Equations}

$$
\begin{array}{cr}
V d=\frac{V_{c}}{\gamma_{c}}+\frac{V_{s}}{\gamma_{s}} & \begin{array}{c}
\text { Determination of design shear resistance, using the division by } \gamma \\
V d=\phi_{c} \cdot V_{c}+\phi_{s} \cdot V_{s}
\end{array} \\
\phi=\frac{V d}{V_{u}}=\frac{\phi_{c} \cdot V_{c}+\phi_{s} \cdot V_{s}}{V_{c}+V_{s}} & \begin{array}{r}
\text { Determination of design shear resistance, using multiplication by } \Phi \\
\text { Coefficients of ultimate safety factor, } \Phi, \text { being } \Phi \text { mat: partial safety } \\
\text { coefficient provided by the variability and the possibility of a low } \\
\text { material strength and } \Phi \text { mod: safety coefficient provided by the } \\
\text { inaccuracy of the model representation }
\end{array} \\
\phi_{\text {mat }} \cong \phi_{\text {mat }} \cdot \phi_{\text {mod }} \cong \sqrt{\phi} & \text { Assumption used to define } \Phi \text { mat and } \Phi \text { mod }
\end{array}
$$


Figure 1 - Comparison criteria intervals for Test shear force, $V_{\text {exp }} . V_{d}-$ Design Value, $\mathrm{V}_{\text {seg }}$ - Reliable limit value, $\mathrm{V}_{\mathrm{u}}$ - Ultimate analytical value, and $\mathrm{V}_{\text {one }}$ - Onerous limit value

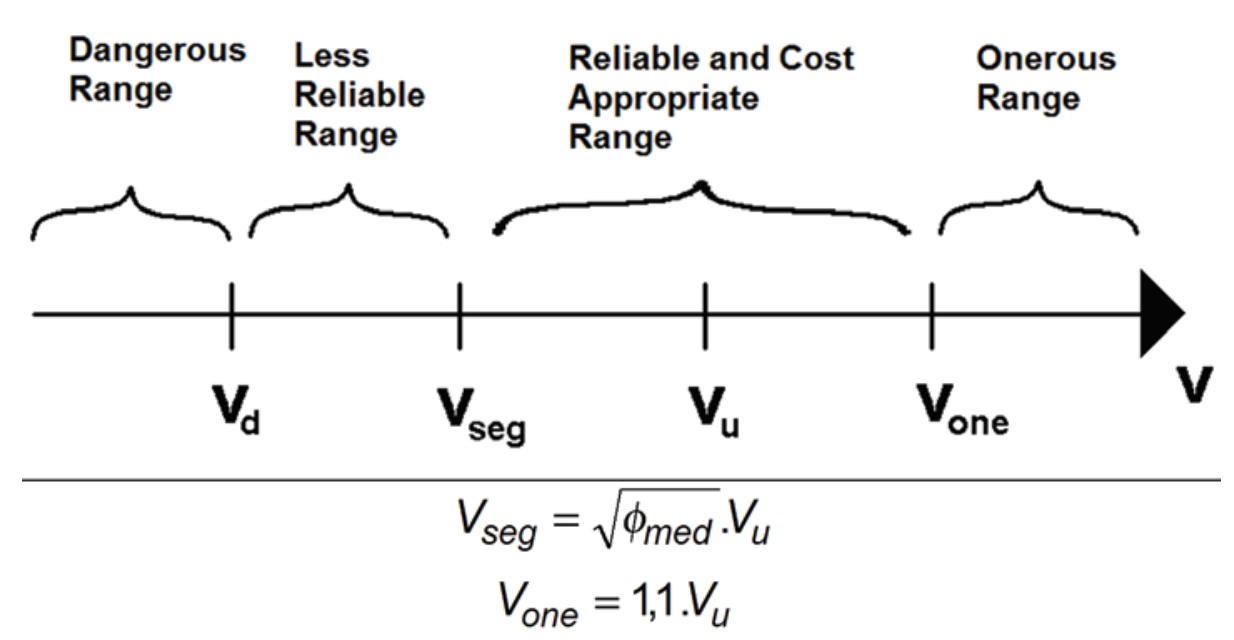

was equal to 0.78 , and the value of 0.90 to $\Phi_{\text {mod }}$ was adopted. As the analysis criteria should be the same for all codes, the partial safety factor $\Phi_{\text {med }}$ is to be determined as an average value of all Codes prediction models.

Thus, the four groups of Table 4 were defined for "reinforced concrete with stirrups cases" and are shown at Table 5.

\section{Results}

From the analysis criteria defined in previous section, charts were made indicating data percentage, $V_{\text {exp }} / V_{n}$, according to each given range, and show in Table 4 and Table 5.

For each equation from Codes' prediction models $\left(V_{\mathrm{d}}, V_{\mathrm{seg}}, V_{\mathrm{u}} \mathrm{e}\right.$ $V_{\text {one }}$ ) a comparison was made with a laboratory test result $V_{\text {exp }}$. Based on those results and on Table 4 analysis criteria, the percentage of data belonging to each range (first to fourth) was stated. Analysis charts were shown containing the four ranges in its respective codes.

\subsection{Analysis of reinforced concrete beams with stirrups}

In order to organize the findings will be presented results obtained in the analysis of the values of the predictions models of codes and experimental values for reinforced concrete elements with stirrup.

\subsubsection{RC beam with stirrups, "valid" parameters and shear-tensile failure}

All the parameters are considered within the Codes requirements. Mechanical Ratio of Stirrups, psw.fyk, lower than $1 \mathrm{MPa}$

According to Figure 2, it is possible to consider:

- NBR 6118 (2007) Model I is less recommended, because it presented $2 \%$ of the cases in range 1 (considered less reliable).

n NBR 6118 (2007) Model II is less recommended as well, because $8 \%$ of the results are in range 1 .
EUROCODE (2004) prediction model presented a fair result, although $89 \%$ of the results are in range 4 (considered costly in monetary terms).

- $\mathrm{ACl}$ (2008) prediction models showed good results, being the recommended on among the previous three analyses, presenting $15 \%$ of results in range 3 , and irrelevant values for ranges 1 and 4 .

- CSA (2004) model had fair results, due to great results in range 3 .

\begin{tabular}{|cc|}
\hline \multicolumn{2}{|c|}{ Table 4 - Intervals of comparison criteria } \\
Comparison criteria & Description \\
$V_{\text {Exp }}<\phi_{\text {med }} \cdot V_{u}$ & Dangerous \\
$\phi_{m e d} \cdot V_{u} \leq V_{E x p}<\sqrt{\phi}$ & Less reliable \\
$\sqrt{\phi_{m e d}} \cdot V_{u} \leq V_{E x p} \leq 1,1 . V_{u}$ & Reliable and costly \\
$V_{E x p}>1,1 . V_{u}$ & appropriate \\
\hline
\end{tabular}

\section{Table 5 - Definition of the third interval of Table 4 for elements with stirrups}

\begin{tabular}{|c|c|c|}
\hline Elements & Comparison criteria & Description \\
\hline With stirrup & $0,9 \cdot V_{u} \leq V_{E x p} \leq 1,1 \cdot V_{u}$ & $\begin{array}{c}\text { Reliable } \\
\text { and costly } \\
\text { appropriate }\end{array}$ \\
\hline
\end{tabular}


Figure 2 - Application of comparison criteria for $\rho_{\mathrm{sw}} \cdot \mathrm{f}_{\mathrm{yk}} \leq 1 \mathrm{MPa}$, defined in this paper, for elements with valid parameters and stirrups

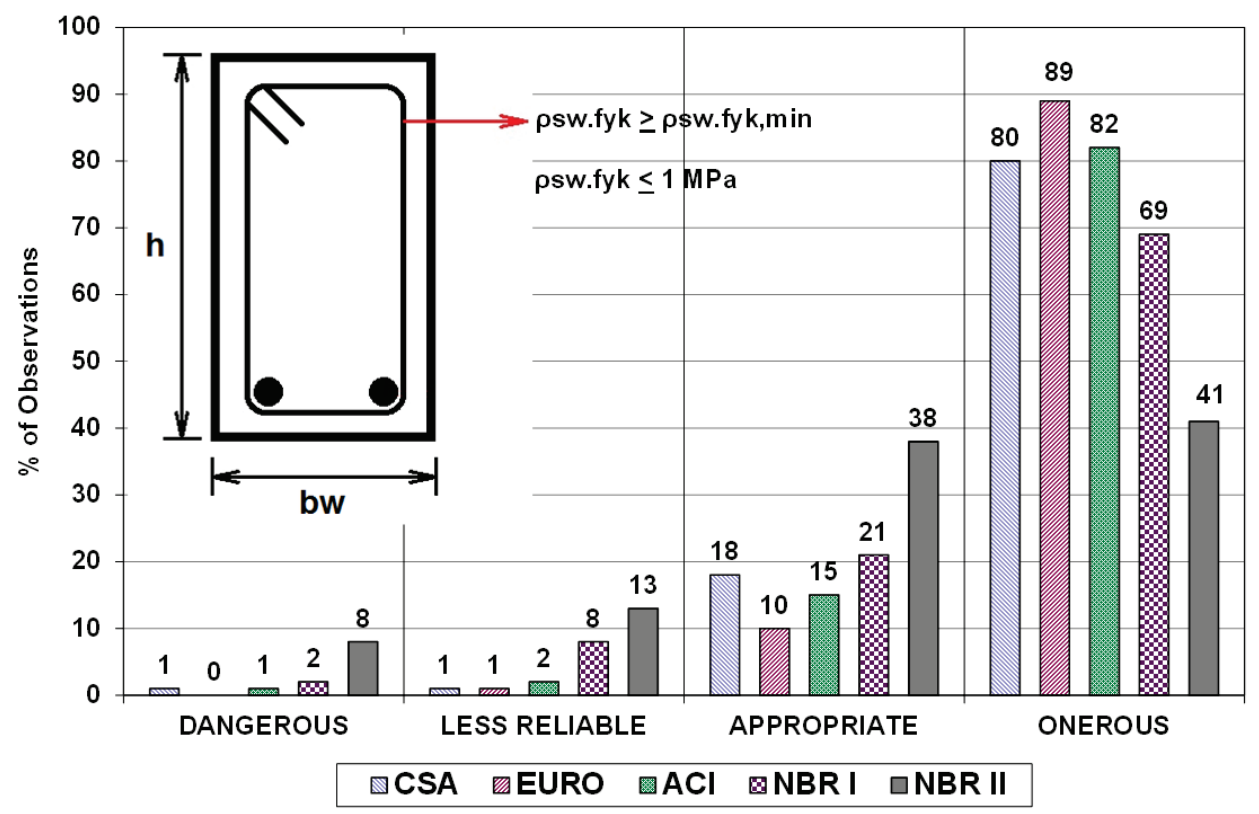

Mechanical Ratio of Stirrups, psw.fyk, greater than $1 \mathrm{MPa}$ and lesser than $2 \mathrm{MPa}$
According to Figure 3, EUROCODE (2004) model presented unsatisfactory results due to its unreliability, presenting $12 \%$ of

Figure 3 - Application of comparison criteria for $\rho_{\mathrm{sw}} \cdot \mathrm{f}_{\mathrm{yk}}$ between 1 and $2 \mathrm{MPa}$, defined in this paper, for elements with valid parameters and stirrups

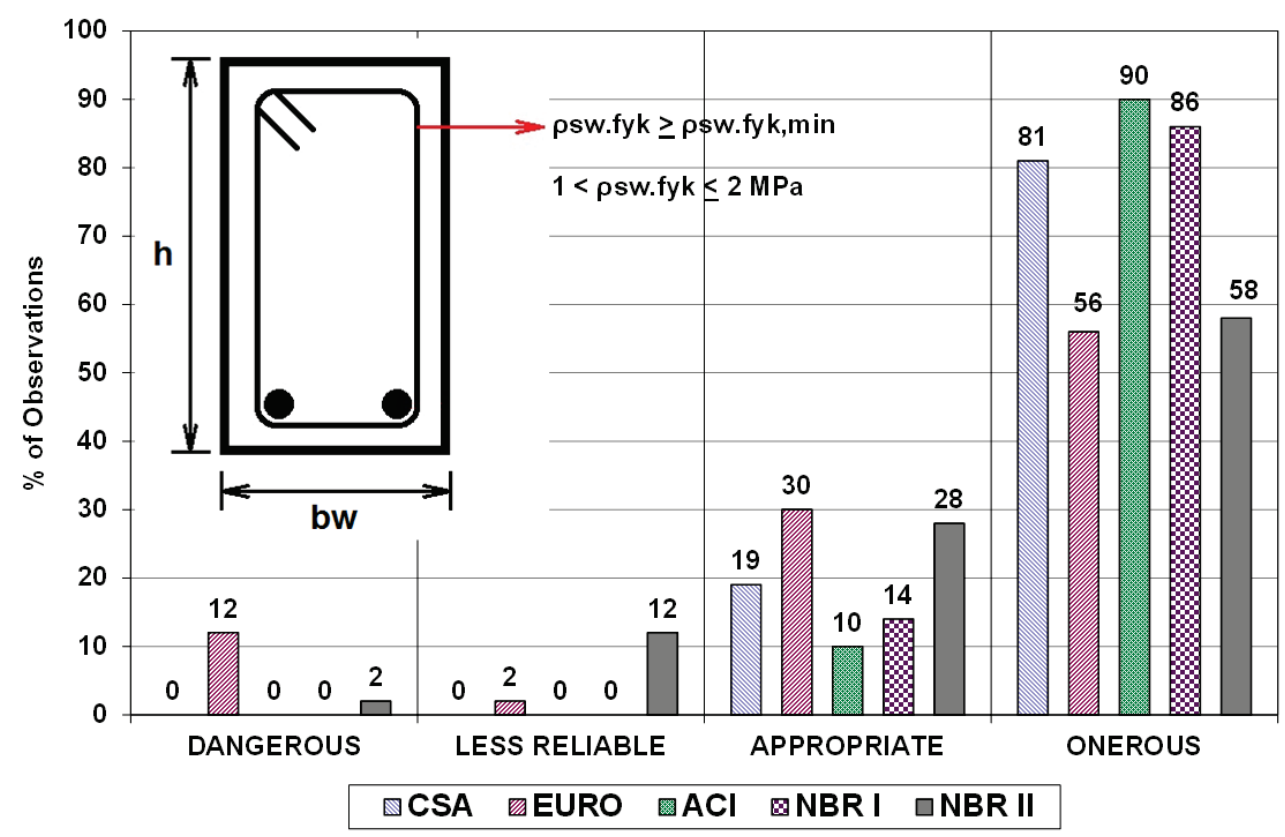


Figure 4 - Application of comparison criteria for $\rho_{s w} \cdot f_{y k}$ greater than $2 \mathrm{MPa}$, defined in this work, for elements with valid parameters and stirrups

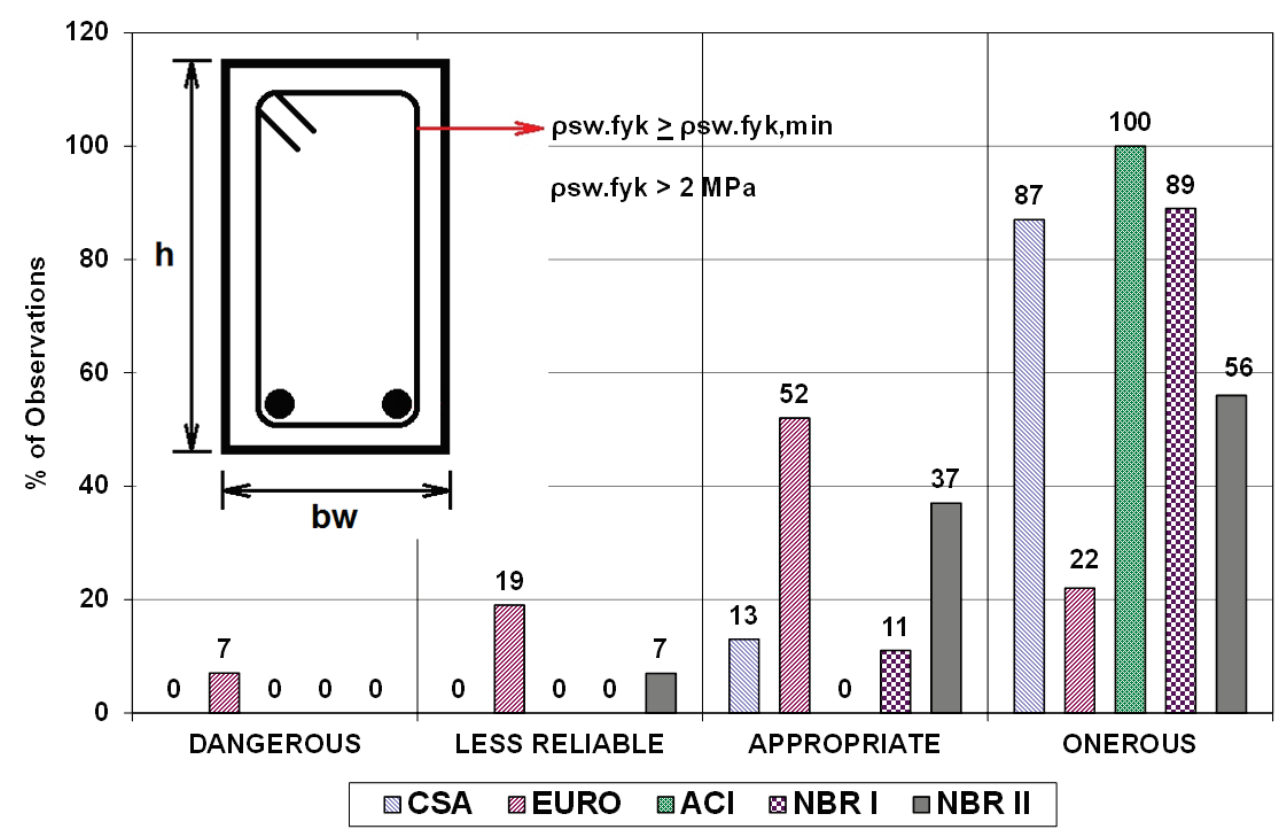

the case scenarios within range 1.

- As NBR 6118 (2007) Model II presented 2\% within range 1, it was considered less recommended.
- NBR 6118 (2007) Model I presented 86\% of results within range 4. Although onerous monetarily, its use is recommended with caution.

Figure 5 - Distribution of models results, according to the comparison criteria for elements with stirrups and mechanical reinforcement ratio less than the minimum (invalid range)

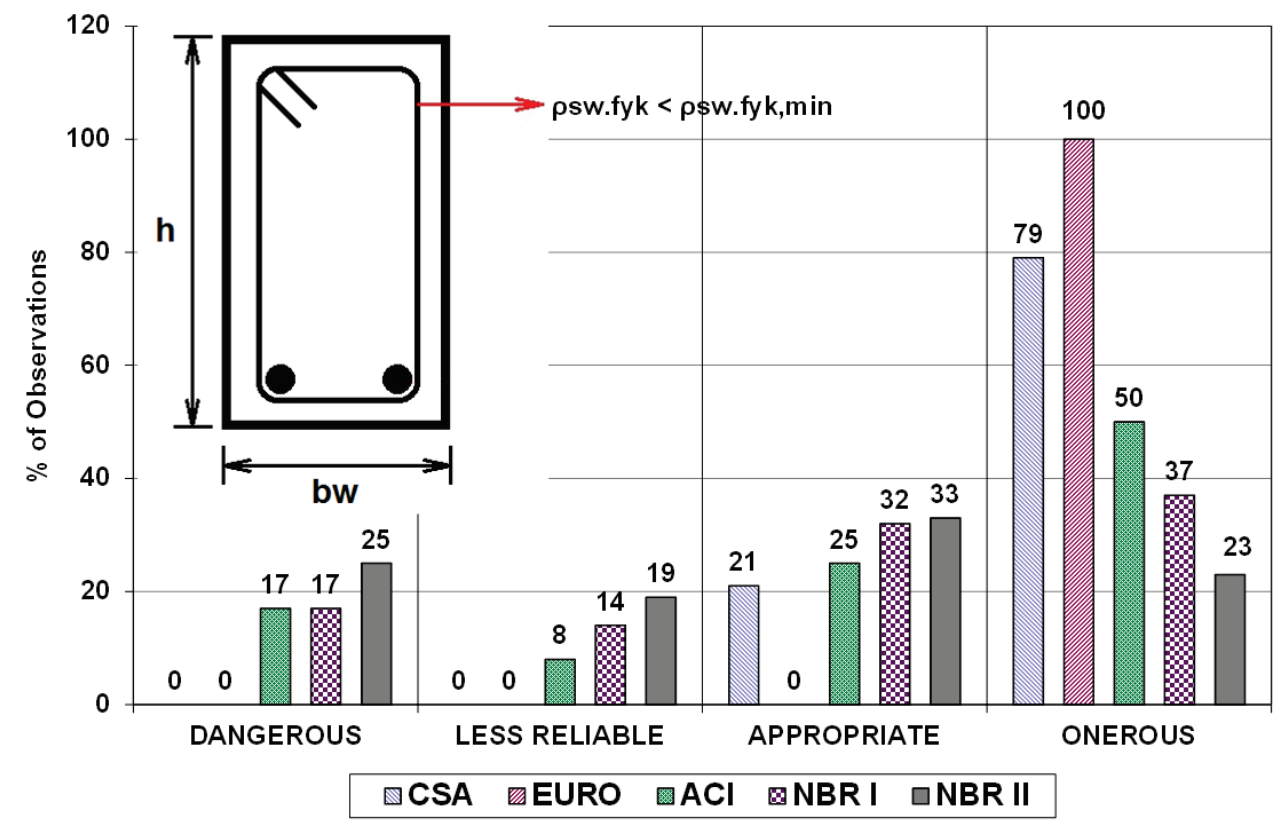


Table 6 - Database used for beams with stirrup elements under axial stress

\begin{tabular}{|c|c|c|c|c|c|c|c|c|c|}
\hline Author & $\begin{array}{l}\text { Number } \\
\text { of tests }\end{array}$ & $\mathrm{b}_{\mathrm{w}}(\mathrm{cm})$ & $\mathrm{d}(\mathrm{cm})$ & $f_{c}(M P a)$ & $\rho_{1} \%$ & $\rho_{\mathrm{sw}} \%$ & $\mathbf{a} / \mathbf{d}$ & $\begin{array}{c}\sigma_{n} \\
(M P a)^{*}\end{array}$ & $\begin{array}{c}\rho_{\text {sw.fyk }} \\
\text { (MPa) }\end{array}$ \\
\hline $\begin{array}{l}\text { Mattock and } \\
\text { Wang (1984) }\end{array}$ & 11 & 15,0 & 31,5 & $24,5-26$ & 2,61 & $0,23-0,46$ & 2,87 & -12 a 0 & $0,83-1,66$ \\
\hline $\begin{array}{l}\text { Haddadin, Hong } \\
\text { and Mattock (1971) }\end{array}$ & 21 & 17,8 & 38,0 & $15,5-30,2$ & 3,81 & $0,19-1,22$ & $2,5-4,25$ & -5 a 3 & $0,68-4,78$ \\
\hline \multirow[t]{2}{*}{ TOTAL } & 32 & 15 - 17,8 & $31,5-38,1$ & $15,5-30,2$ & $2,61-3,81$ & 0,19 - 1,22 & $2,5-4,25$ & -12 a 3 & $0,68-4,78$ \\
\hline & & & ${ }^{*} \mathrm{Com}$ & ession $<0$ e & Tensile $>0$ & & & & \\
\hline
\end{tabular}

$\mathrm{ACl}$ (2008) model is recommended for this case scenario, although there are $90 \%$ of the results in range 4 and $10 \%$ in range 3 .

- The calculation model I of NBR 6118 (2007) presented $86 \%$ of the predictions considered onerous, although safe. Therefore, its use is recommended with caution.

- CSA (2004) models presented no results in ranges 1 and 2, $19 \%$ in range 3 and $81 \%$ in range 4 , being considered the most recommended for this case scenario.

Mechanical Ratio of Stirrups, psw.fyk, greater than $2 \mathrm{MPa}$

- According to Figure 4, EUROCODE Prediction model showed unsatisfactory results in terms of reliability, due to a $7 \%$ rate in range 1 .

- ACl (2008) model present a full rate inside range 4. Although onerous, it was considered a fair result.

- NBR 6118 (2007) presented 89\% inside range 4, being also considered a fair result. The code model of CSA (2004) showed no results within ranges 1 and $2,19 \%$ in range 3 and $89 \%$ in range 4 .
NBR 6118 (2007) presented satisfactory results with 37\% in range 4 and $56 \%$ in range 3 , being recommended its use.

\subsubsection{RC beam with stirrups, "denied" parameters and shear-tensile failure}

Mechanical Ratio of Stirrups, psw.fyk, lesser than Codes minimum requirement, $\rho s w . f y k$, min

According to Figure 5, NBR 6118 (2007) Model I is less recommended, because there is $25 \%$ of the results within range 1 . Model II is also less recommended, presenting $17 \%$ of the results within the same range.

$\mathrm{ACl}$ (2008) models presented $17 \%$ of results in range 1 , being considered less recommended as well.

EUROCODE (2004) models presented $100 \%$ of results inside range 4 , being all reliable, although costly.

Figure 6 - Reliability analysis for cases under compression, for elements with stirrups

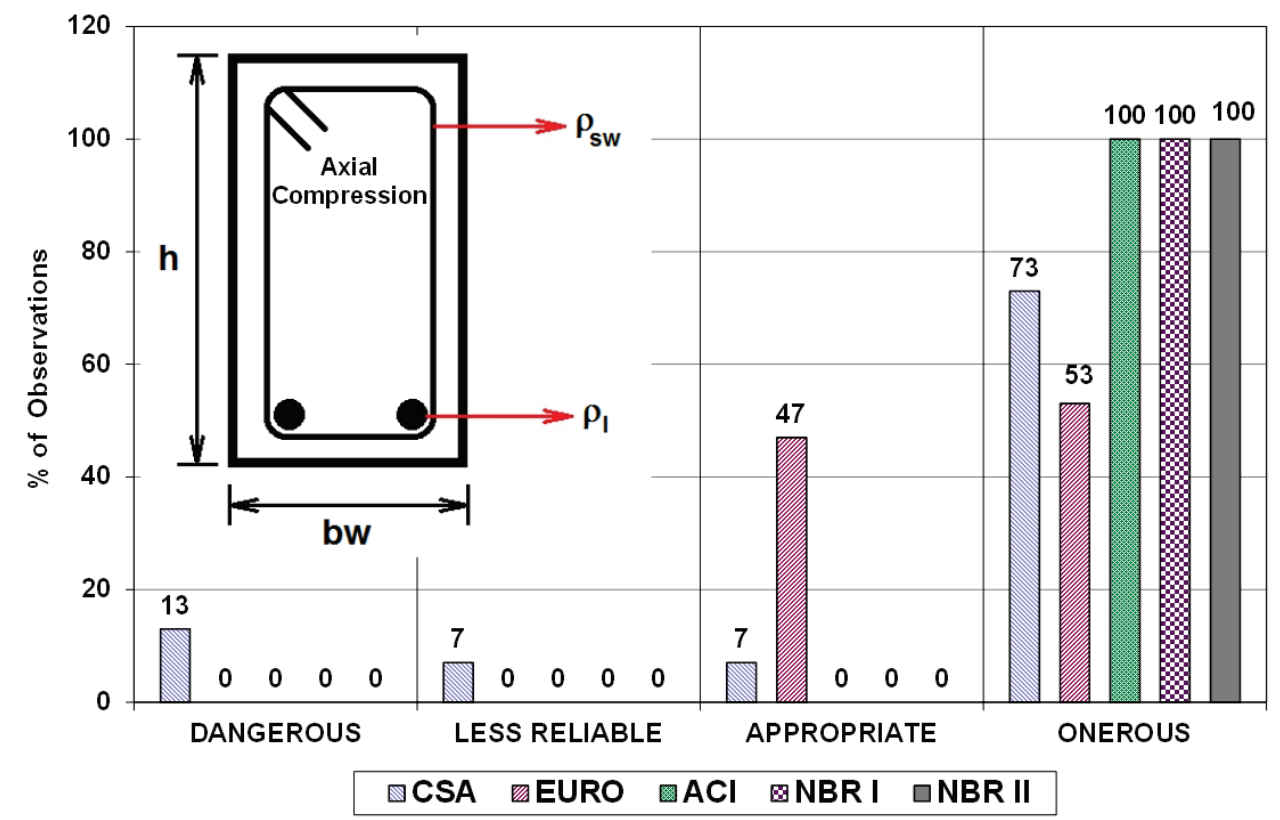


Figure 7 - Reliability analysis for cases under tension, for elements with stirrups

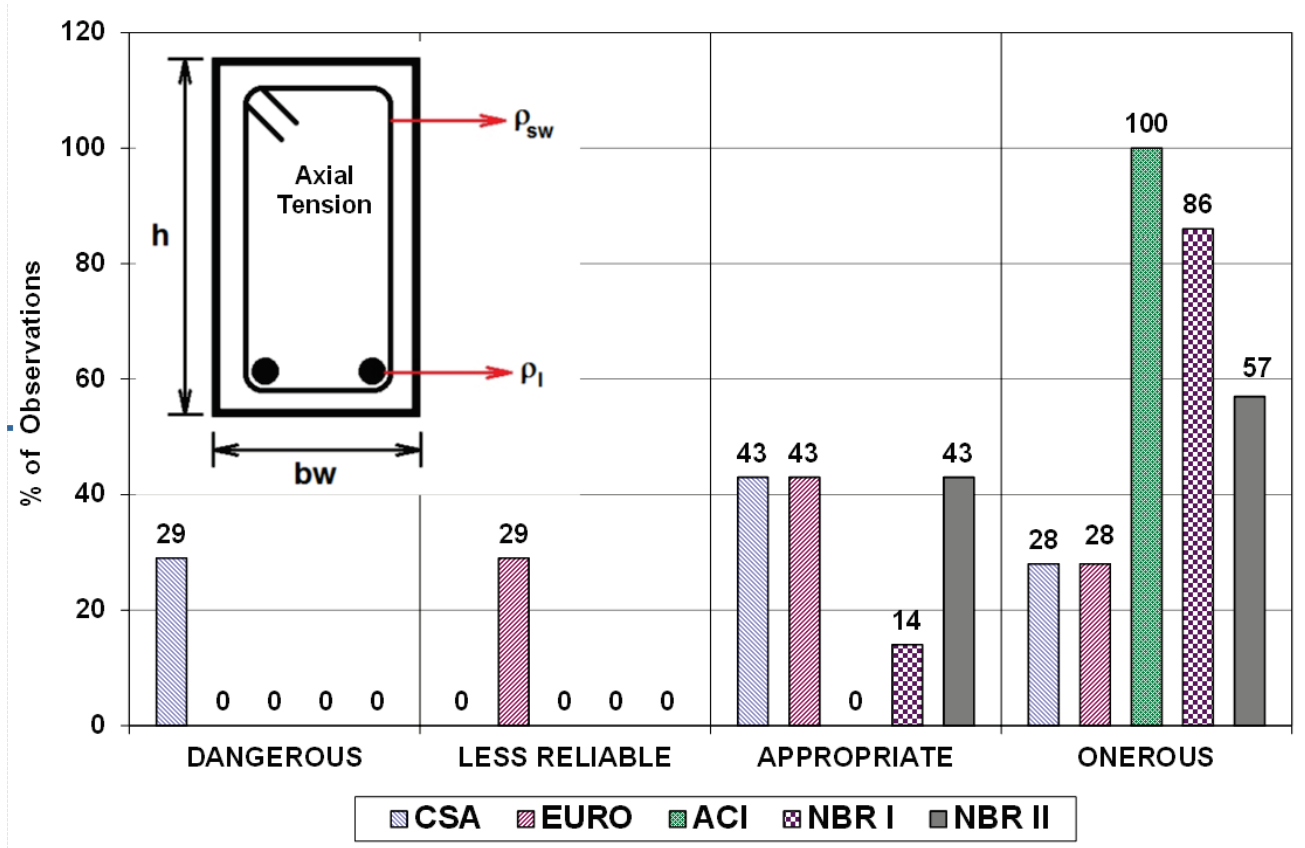

Considered recommended to use, CSA (2004) models presented $79 \%$ of results inside range $4,21 \%$ in range 3 and no results in range 1 or 2 .

\subsubsection{RC Beams with stirrups under axial loading and shear-tensile failure}

The summary of the database is presented in Table 6 .

\section{$R C$ under axial compression}

Figure 6 illustrates the reliability of reinforced concrete elements with stirrups under axial compression. CSA (2004) was considered less recommended because it presented $13 \%$ of the results in range 1.
NBR 6118 (2007) Models I and II, as well as ACI (2008) model presented $100 \%$ of their results within range 4 , being considered reliable, although onerous. Thus, these models have been qualified for use as recommended with caution due to higher costs.

EUROCODE (2004) models showed $53 \%$ of results in range 4 , while $47 \%$ was considered appropriate (range 3 ). Thus, it was considered recommended for use in these conditions.

\section{RC Beams under axial tensile loading}

Figure 7 represents this scenario.

While CSA (2004) models presents $29 \%$ of results in range 1 , EUROCODE (2004) presented the same amount in range 2 . Since element under axial tensile loading is an issue when designing RC

Table 7- Qualification of prediction's models, for safety use, for elements with stirrups

\begin{tabular}{|c|c|c|c|c|c|c|}
\hline & \multicolumn{6}{|c|}{ Elements with stirrups } \\
\hline & \multicolumn{3}{|c|}{ Valid ranges } & \multirow{2}{*}{$\begin{array}{l}\text { Invalid ranges } \\
\rho_{\mathrm{sw}} \mathrm{f}_{\mathrm{yk}} \leq \boldsymbol{\rho}_{\mathrm{sw}} \mathrm{f}_{\mathrm{yk}, \mathrm{min}}\end{array}$} & \multicolumn{2}{|c|}{ Axial stress } \\
\hline & $\rho_{s w} f_{y k} \leq 1$ & $1<\rho_{s w} \cdot f_{y k} \leq 2$ & $\rho_{\mathrm{sw}} \mathrm{f}_{\mathrm{yk}}>2$ & & Compression & Tensile \\
\hline CSA & R & R & $\mathrm{CC}$ & $\mathrm{R}$ & LS & LS \\
\hline EURO & $\mathrm{CC}$ & LS & LS & $\mathrm{CC}$ & R & LS \\
\hline $\mathrm{ACl}$ & $\mathrm{R}$ & $\mathrm{CC}$ & $\mathrm{CC}$ & LS & $\mathrm{CC}$ & $\mathrm{CC}$ \\
\hline NBR I & LS & $\mathrm{CC}$ & $\mathrm{CC}$ & LS & $\mathrm{CC}$ & $R$ \\
\hline NBR ॥ & LS & LS & R & LS & $\mathrm{CC}$ & R \\
\hline
\end{tabular}


Table 8 - Abbreviations used to qualify prediction models in code regarding its use

\begin{tabular}{|ccc|}
\hline Qualification regarding the use & Abbreviations & Criferia * \\
Recommended & R & \% Dangerous $>1 \%$ \\
Less recommended for safety reason & LS & $\%$ Onerous $\geq 85 \%$ \\
Caution/Cost & CC & $\%$ Less Reliable $\geq 10 \%$ \\
Caution/Safety & CS & \\
\hline * Criterion for guidance & & \\
\hline
\end{tabular}

structures, ACl's results were also considered less recommended. $\mathrm{ACl}$ (2008) models showed $100 \%$ of results within range 4 .

NBR 6118 (2007) Models I and II presented the best results for this scenario with, respectively, $86 \%$ and $57 \%$ within range 4 . There was no percentage within ranges 1 and 2 and respectively $14 \%$ and $43 \%$ of results in range 3 . Both models are recommended for use in such conditions.

\section{Conclusions}

Table 7 presents a summary of all analyzes performed in this paper, based on analysis criteria, explained in previous sections. In this table there are conclusions on reliability of $\mathrm{RC}$ concrete beams with stirrups.

In order to clarify, acronyms are indicated and properly described in Table 8.

The nomenclature "less recommended for safety reasons", "NR", was used on each Code that presented more than $1 \%$ of results within range 1.

Defined as Caution / Cost, "CC" is named for all the cases that presented at least more than $85 \%$ within range 4 . In this case, caution is recommended because although the structure can be reliable, elevated costs can be considered for that design.

Caution/Safety, "CS", indicates all the codes with more than $10 \%$ of results in range 2 , because some results can influence a decrease in certain safety coefficients factors.

Since the nomenclatures are presented and described, final conclusions can be made in the following paragraphs.

In order to obtain the maximum value for ultimate shear strength, all codes equations were taken into account so this could be done. Example given, when using NBR 6118 (2007) Model II, in order to obtain the ultimate shear strength, the minimum strut angle took into account considerations on concrete's strut crushing and yielding phenomena on bending reinforcement.

The term "safe" used on "Caution/Safety" is not related to Codes safety. When this paper recommends not to use a certain Code due to lack of safety, it is related to the prediction models reliability. The analysis criteria presented in this paper, all the laboratory results from the database and the prediction models results, helped to organize in a simple and clear way different manners of designing a $\mathrm{RC}$ beams under shear loading.

Table 9 indicates which models are recommended and less recommended for designing purposes. The recommended Codes are those which presented safe prediction results and, possibly, less costly when considering material consumption. Also, there can be found in Table 9 the conclusions for all the analysis on a RC beam with stirrups within the four ranges.

Table 9 shows that CSA (2004) models are recommended in 2 out of 5 scenarios; NBR 6118 (2007) are the most recommended in 2 cases, and finally, ACI (2008) and EUROCODE (2004) are recommended for one case each.

NBR 6118 (2007) models were less recommended for mechanical ratio of stirrups lesser than $1 \mathrm{MPa}$. Model II was the least recommended for ratios lesser than $2 \mathrm{MPa}$. For both models, the use of minimum transverse reinforcement must be taken into account.

CSA (2004) models, based on the Modified Compression Field Theory, showed for elements without axial loading the best average of cases defined as recommended for use. For members under compression load-

\section{Table 9 - Prediction models recommended and less recommended for analysis of elements with stirrups, being: CSA - CSA (2004), EURO - Eurocode (2004), ACI - ACI (2008), NBR I - I model the NBR 6118 (2007) NBR and II - II model of NBR 6118 (2007)}

\begin{tabular}{|c|c|c|c|c|c|}
\hline \multirow{3}{*}{$\begin{array}{l}\text { Qualification of } \\
\text { the prediction model }\end{array}$} & \multicolumn{5}{|c|}{ Elements with stirrups } \\
\hline & \multicolumn{3}{|c|}{ Valid ranges } & \multicolumn{2}{|c|}{ Axial stress } \\
\hline & $\rho_{s w} \cdot f_{y k} \leq 1$ & $1<\rho_{s w} \cdot f_{y k} \leq 2$ & $\rho_{s w} \cdot f_{y k}>2$ & Compression & Tensile \\
\hline Most recommended & $\mathrm{CSA} / \mathrm{ACl}$ & CSA & NBR ॥ & EURO & NBR I e NBR I| \\
\hline Less recommended & NBR I/NBR II & EURO/NBR II & EURO & CSA & CSA/EURO \\
\hline
\end{tabular}


ing EUROCODE (2004) models showed good results, while the most recommended models under tensile loadings were NBR 6118 (2007). It is noticeable that when the strut's angle on Model II is equal to $39^{\circ}$, the results are similar to those calculated by Model I. Therefore, as long as there is a limitation on $39^{\circ}$ on strut angle, both models can give the same results.

\section{Acknowledgments}

Acknowledgements to Professor Maria Elena Santos Taqueda.

\section{Bibliography}

[01] ASSOCIAÇÃO BRASILEIRA DE NORMAS TÉCNICAS. NBR 6118: Projeto de estruturas de concreto Procedimento. Rio de Janeiro, Brasil, 2007. 221 p.

[02] LEONHARDT, F.; MÖNNIG, E. Construções de concreto - Princípios básicos do dimensionamento de estruturas de concreto armado. v.1, Rio de Janeiro, Ed. Interciência, 1982, 305p.

[03] AMERICAN CONCRETE INSTITUTE (ACI), Committee 318: Building Code Requirements for Structural Concrete and Commentary (ACl 318-08), Detroit, 2008, $479 \mathrm{p}$.

[04] CANADIAN CODES ASSOCIATION. CSAA23.3-04 Code - Design of concrete structures. Ontario, Canadá, 2004. 240 p.

[05] BRITISH CODES INSTITUTION, BS EN 1992-1-1:2004 - Eurocode 2. Reino Unido, 2004. 230 p.

[06] FUSCO, P. B. Estruturas de Concreto: Solicitações Tangenciais. 1. ed. São Paulo: Editora PINI Ltda., 2008. V.1. 328 p.

[07] ANDERSON, N.S.; RAMIREZ, J.A. Detailing of stirrup reinforcement. ACI Structural Journal, V.86, N.5, 1989. p.507-515.

[08] ANGELAKOS, D.; BENTZ, E.C.; COLLINS, M.P. Effect of concrete strength and minimum stirrups on shear strength of large members. ACI Structural Journal, V.98, N.3, 2001. p.290-300.

[09] BRESLER, B.; SCORDELIS, A.C. Shear strength of reinforced concrete beams. $\mathrm{ACl}$ Journal Proceedings. V.60, N.1, 1963. p.51-74.

[10] CHO, S.H. Shear strength prediction by modified plasticity theory for short beams. ACI Structural Journal, V.100, N.1, 2003, p.105-112.

[11] CLADERA, A. ; MARI, A.R. Experimental study on high-strength concrete beams failing in shear. Engineering Structures, V.27, 2005, p.1519-1527.

[12] COLLINS, M.P.; KUCHMA, D. How Safe Are Our Large, Lightly Reinforced Concrete Beams, Slabs and Footings? ACI Structural Journal, V.96, N.4, 1999. p.482-490.

[13] DEBAIKY, S.Y. ; ELNIEMA, E.I. Behavior and Strength of Reinforced Concrete Haunched Beams in Shear. ACI Journal, 1982, p.184-194.

[14] ELZANATY, A.H. ; NILSON, H. ; SLATE, F.O. Shear capacity of reinforced concrete beams using high-strength concrete. $\mathrm{ACl}$ Structural Journal, V.83,

N.2, 1986, p.290-96.
[15] FERNANDES, G. B. Behavior of Reinforced High-Strength Concrete Corbels - Experimental Investigation and Design Model. ACI Structural Journal, V.186, 1999. p. 445-462.

[16] FUKUHARA M, KOKUSHO S. Effectiveness of high tension shear reinforcement in reinforced concrete members. Journal of the Structural Construction Engineering, AlJ 320, 1982, p.12-20

[17] HADADDIN, M.J.; HONG, S.; MATTOCK, A.H. Stirrup Effectiveness in Reinforced Concrete Beams with Axial Force. Journal of Structural Division Proceedings of the ASCE, V.97, N.9, 1971. p.2277-2297.

[18] HSIUNG, W. ; FRANTZ, G.C. Transverse Stirrup Spacing in R/C Beams. American Society of Civil Engineers, ASCE, V.111, N.2, 1985, p.353-363.

[19] KREFELD W.J.; THURSTON C.W. Studies of the shear and diagonal tension strength of simply supported reinforced concrete beams. ACI Journal Proceedings, V.63, N.4, 1966, p.451-476.

[20] LEE, J.Y. ; KIM, S.W. ; MANSOUR, M.Y. Predicting the shear response of reinforced concrete beams using a new compatibility aided truss model. ACI Structural Journal, 2002.

[21] MATTOCK, A. H.; WANG, Z. Shear Strength of Reinforced Concrete Members Subject to High Axial Compressive Stress. ACI Structural Journal, V.81, N.3, 1984. p. 287.

[22] MORETTO, O. An investigation of the strength of welded stirrups in reinforced concrete beams. ACl Journal, Proceedings, V.42, N.2, 1945, p.141-162.

[23] MPHONDE, A.G.; FRANTZ, G.C. Shear Tests of High and Low-Strength Concrete Beams without Stirrups. ACI Journal, Proceedings, V.81, N.4, 1984. p.350-357.

[24] OZCEBE, G. ; ERSOY, U. ; TANKUT, T. Evaluation of minimum shear reinforcement requirements for higher strength concrete. ACI Structural Journal, V.96, N.3, 1999, p.361-368.

[25] PENG L. Shear strength of beams by shear friction. M.A.Sc. thesis, the University of Calgary, Calgary, Alberta, 1999.

[26] PLACAS, A.; REGAN, P. E. Shear Failure of Reinforced Concrete Beams. ACl Journal, Proceedings, V.68, N.10, 1971. p.763-773.

[27] RAJAGOPALAN, K.S. ; FERGUSON, P.M. Exploratory shear tests emphasizing percentage of longitudinal steel. ACI Journal, V.65, N.8, 1968, p.634-38.

[28] RANGAN, B.V. Web Crushing Strength of Reinforced and Prestressed Concrete Beams. ACI Structural Journal, V.88, N.1, 1991. p.12-16.

[29] RODRIGUEZ JJ, BIANCHINI AC, VIEST IM, KESLER $\mathrm{CE}$. Shear strength of two-span continuous reinforced concrete beams. ACl Journal, Proceedings, V.55, N.10, 1959, p.1089-1130.

[30] ROLLER, J.J. ; RUSSELL, H.G. Shear strength of high-strength concrete beams with web reinforcement. ACI Structural Journal, V.87, N.2, 1990, p.191-198.

[31] SARSAM, K.F.; AL-MUSAWI, J.M.S. Shear Design of High- and Normal Strength Concrete Beams with Web Reinforcement. ACI Structural Journal, V.89, N. 6, 1992. p. 658-664. 
[32] SIMPLICIO, M.A.S. ; ÁVILA, J.I.S.L. Avaliação da capacidade resistente a força cortante em vigas segundo a NBR 6118:2003. IN: Anais $47^{\circ}$ Congresso Brasileiro do Concreto, IBRACON, CBC2005, ISBN 85-98576-07-7, V. XII - Projetos de Estruturas de Concreto, Trabalho 47CBC0142, Set/2005, 8p.

[33] TOMPOS, E.J.; FROSH, R.J. Influence of Beam Size, Longitudinal Reinforcement, and Stirrup Effectiveness on Concrete Shear Strength. ACI Structural Journal, V.99, N. 5, 2002. p.559-567.

[34] XIE, L.; BENTZ, E. C.; COLLINS, M. P.Influence of Axial Stress on Shear Response of Reinforced Concrete Elements. ACI Structural Journal,V.108, N.6, 2011. p. 745.

[35] YOON, Y.S.; COOK, W.D.; MITCHELL, D. Minimum Shear Reinforcement in Normal, Medium and High-Strength Concrete Beams. ACI Structural Journal, V.93, N.5, 1996., p.576-584.

[36] ZARARIS, P.D. ; PAPADAKIS, G.C. Diagonal shear failure and size effect in RC beams without web reinforcement. Journal Structural Engineering, ASCE, 127(7), 2001, p.733-742.

[37] ZARARIS, P.D. Shear strength and minimum shear reinforcement of reinforced concrete slender beams. ACI Structural Journal, V.100, N.2, 2003. p.203-214.

[38] REINECK, K.H.; KUCHMA, D.A; FITIK, B. Extended databases with shear tests on structural concrete beams without and with stirrups for the assessment of shear design procedures. University of Stuttgart, University of Illinois, 2010.

[39] COLLINS, M.P; BENTZ, E.C.; SHERWOOD, E.G. Where is Shear Reinforcement Required? Review of Research Results and Design Procedures. $\mathrm{ACl}$ Structural Journal, V.105, N.5, 2008. p. 590.

[40] BENTZ, E.C. Sectional Analysis of Reinforced Concrete Members. Tese (Doutorado), University of Toronto, 2000, 316p.

[41] CLADERA, A. Shear Design of Reinforced High-Strength Concrete Beams. Tese de doutorado, Universitat Politècnica de Catalunya, Barcelona, Espanha, 2002. 284p.

[42] BETTE,S.C. Avaliação da precisão dos modelos de cálculo da NBR 6118/03 para o dimensionamento de vigas de concreto armado ao esforço cortante. FAPESP, Relatório final de bolsa de iniciação científica, Bauru/SP, 2007.

[43] CLADERA, A. Shear Design of Reinforced High-Strength Concrete Beams. Tese de doutorado, Universitat Politècnica de Catalunya, Barcelona, Espanha, 2002. 284p.

[44] ACHARYA DN, KEMP K.O. Significance of dowel forces on the shear failure of rectangular reinforced concrete beams without web reinforcement. $\mathrm{ACl}$ Journal, 62-69, 1965, p.1265-1278.

[45] AHMAD, S.H. ; KHALOO, A.R. ; POVEDA, A. Shear capacity of reinforced high-strength concrete beams. ACI Journal, March-April 1986, p.297-305.

[46] BAZANT, Z. P.; KAZEMI, M.T. Size Effect on Diagonal Shear Failure of Beams without Stirrups. $\mathrm{ACl}$
Structural Journal, V.88, N. 3, 1991. p.268-276.

[47] BENTZ, E.C. ; BUCHLEY, S. Repeating a classic set of experiments on size effect in shear of members without stirrup. ACI Structural Journal, V.102, N.6, 2005, p.832-838.

[48] GHANNOUM, W.M. Size effect on shear strength of reinforced concrete beams. M.E. thesis, Department of Civil Engineering and Applied Mechanics, McGill University, Montreal, 1998.

[49] KANI, G.N. How Safe are Our Large Concrete Beams?. ACl Journal, Proceedings, V.64, N.3, 1967. p.128-141.

[50] KIM, D.; KIM, W.; WHITE, R.N. Arch Action in Reinforced Concrete Beams - A Rational Prediction of Shear Strength. ACI Structural Journal, V.96, N.4, 1999. p. 586-593.

[51] MATHEY, R.G. ; WATSTEIN, D. Shear strength of beams without web reinforcement containing deformed bars of di.erent yield strengths. ACl Journal Proceedings, V.63, 1963, p.183-206.

[52] MORROW, J.; VIEST, I.M. Shear Strength of Reinforced Concrete Frame without Web Reinforce ment. ACI Journal, Proceedings, V.28, N.9, 1957. p.833-869.

[53] MPHONDE, A.G.; FRANTZ, G.C. Shear Tests of High and Low-Strength Concrete Beams without Stirrups. ACl Journal, Proceedings, V.81, N.4, 1984. p.350-357

[54] PODGORNIAK-STANIK, B. The influence of concrete strength, distribution of longitudinal reinforcement, amount of transverse reinforcement, and member size on shear strength of reinforced concrete members. M.A.Sc. thesis, Department of Civil Engineering, The University of Toronto, 1998.

[55] RAJAGOPALAN, K.S. ; FERGUSON, P.M. Exploratory shear tests emphasizing percentage of longitudinal steel. ACI Journal, V.65, N.8, 1968, p.634-38.

[56] TAYLOR, H.P.J. Shear Strength of Large Beams. ASCE Journal of the Structural Division, V.98, 1972, p.2473-2490.

[57] THORENFELDT, E.; DRANGSHOLD, G. Shear Capacity of Reinforced High-Strength Concrete Beams. ACI Special Publication, SP-121, Nov. 1990, p. 129-154.

[58] VAN DEN BERG F.J. Shear strength of reinforced concrete beams without web reinforcement Part 2 factors a.ecting load at diagonal cracking. ACI Journal Proceedings 1962. 